\title{
LAW
}

JOURNAL

\begin{tabular}{lll}
\hline \hline Vol. XXII & FEBRUARY, 1913 & No. 4 \\
\hline \hline
\end{tabular}

\section{THE ESSENTIALS OF A LAW ESTABLISHING AN INTERNATIONAL COURT*}

The First Hague Conference created the permanent Court of Arbitration, which was its highest achievement. The Second Hague Conference proposed the establishment of an International Court of Prize and a Court of Arbitral Justice, and upon these its fame will forever endure. In the First Conference the idea of the creation of an International Court had been promptly laid aside as soon as it was suggested, it being regarded as impracticable, if not impossible. The acceptance of the proposal by forty-five nations in the Second Conference marks the rapid progress of this movement.

An International Prize Court presupposes the existence of war as the capture of private property of neutrals is only permitted in maritime warfare. It is a war court and is without jurisdiction of controversies arising in peace. To establish such a court was indeed desirable, but even more desirable was the establishment of a court which should not presuppose the existence of war, but which should be clothed with authority to pass upon controversies arising in times of peace, and which if not amicably settled might lead to war.

The Permanent Court established in 1899 lacked the essential qualities of a court. To cail it a court at all is decidedly a misnomer, and to apply the term permanent to a tribunal temporary in its character is an even greater fiction. It is a tribunal of arbi-

* Address delivered in Washington, D. C., on December 20, 1912, before the American Society for Judicial Settlement of International Disputes, by Henry Wade Rogers, Dean of the Yale Law School. 
tration with a right in the parties submitting controversies to select their abitrators. The difference between the court of 1899 and the one proposed in 1907 is indicated in the instructions which $\mathrm{Mr}$. Root issued to the American delegation to the Second Conference. He said:

"It lias been a very general practice for arbitrators to act, not as judges decidling questions of fact and law upon the record before them under a sense of judicial responsibility, but as negotiators effecting settlement of the questions brought before them in accordance with the traditions and usages, and subject to all the considerations and influences which affect diplomatic agents. The two methods are radically different, proceed upon different standards of honorable obligation, and frequently lead to widely differing results. It very frequently happens that a nation which would be very willing to submit its differences to an impartial judicial determination, is unwilling to subject them to this kind of diplomatic process. If there could be a tribunal which would pass upon questions between nations with the same impartial and impersonal judgment that the Supreme Court of the United States gives to questions arising between citizens of the different States, or between foreign citizens and the citizens of the United States, there can be no doubt that nations would be more ready to submit their controversies to its clecision than they are now to take the chance of arbitration. Tt slnould be your effort to bring about in the Second Conference a development of the Hague Tribunal into a permanent tribunal composed of judges who are judicial officers and nothing less, who are paid adequate salaries, who have no other occupation, and who will devote their entire time to the trial and decision of international causes by judicial methods and under a sense of judicial responsibility."

The Court of Arbitral Justice is an attempt to realize the ideas involved in Mr. Root's instructions. It is an attempt to set up a real Court composed of real juris-consults with a right to decide questions of a legal nature.

Under the Articles of Confederation, the United States was without a juclicial department, but it was ordained in the Ninth Article that Congress assembled should be the last resort on appeal in all disputes and differences arising between two or more States "concerning boundaries, jurisdiction or any other cause whatever." This authority was to be exercised in the following manner: The legislative or executive authority of a State in controversy with another could present a petition to Congress stating the matter in difference, and praying for a hearing. Thereupon Congress notified the other State and a day was assigned for the appearance of the parties by their agents, and they were then 
directed to appoint by joint-consent, commissions or judges, to constitute a court for hearing and determining the matter in controversy. If they could not agree, Congress was to name three persons out of each of the United States, or from the list of such persons, each party was alternately to strike out one, the petitioners beginning, until the number was reduced to thirteen. From that number not less than seven nor more than nine names, as Congress might direct, were to be drawn out by lot in the presence of Congress. The persons whose names were so drawn, or any five of them, were to be the judges who were to hear and finally determine the controversy. If either party neglected to appear on the day appointed, without showing reasons satisfactory to Congress, that body was to nominate three persons out of each State and the Secretary of Congress was to strike in behalf of the absent party. The judgment of the court thus appointed was to be final and conclusive. Each State was pledged to carry out the award in good faith. No power was conferred upon Congress to enforce the judgment. One case only was actually tried and determined under the authority thus conferred. The case was that of Pennsylvania v. Connecticut. The latter State had for years made claim to the Wyoming Valley, now the County of Luzerne, in. Pennsylvania. The laws of Connecticut were at one time regularly enforced there. The Courts of Connecticut had administered justice there. Taxes had been levied and collected by Connecticut. Levies from that district made the Twenty-fourth Connecticut Regiment in the Continental Army. The Articles of Confederation went into effect in I78I and Pennsylvania at once took advantage of the Ninth Article to apply to Congress for a court to decide upon the Connecticut claim. Congress, which then held its sessions in Philadelphia, granted the request and ordered the court to meet at Trenton in November, 1782. The juiges, after considering the matter for forty-one clays, renderd an opinion in favor of Pennsylvania. Connecticut at once acquiesced. The court had agreed in advance that whatever its decision might be, it was to assign no reasons for it. An experience based on a single case is not of great value. The fact that the defeated sovereignty acquiesced although Congress had no power given it to enforce the judgment, is without much significance. A State as small as Connecticut would not be likely to make war upon a State the size of Pennsylvania over such a controversy. 
There were other cases presented to Congress involving like boundary disputes. That of South Carolina v. Georgia, and that of Massachusetts v. New York. In each of these cases, a court was appointed, but the dispute was settled out of court.

The Supreme Court of the United States has been called "A Tribunal of International Justice". Mr. Webster once referred to the members of it as "the great arbitrators between contending sovereignties". In speaking of the court, De Tocqueville said: "In the nations of Europe, the courts of justice are only called upon to try the controversies of private individuals; but the Supreme Court of the United States summons sovereign powers to its bar." The Constitution gives the court not only jurisdiction of "cases affecting ambassadors, other public ministers and consuls", but it also gives it jurisdiction over controversies between two or more States, and between a State or the citizens thereof and foreign States, citizens or subjects.

The inefficiency of the then existing machinery for the administration of justice to foreigners in Egypt, led to the establishment in that country in 1876 of what have been known as the International Courts. The Powers which have become parties to the arrangement include the United States, Great Britain, Germany, France, Austria, Russia, Italy, Spain, Belgium, the Netherlands, Greece, Denmark, Portugal, Sweden and Norway.

The court which the Conference of 1907 proposes is one differing in important particulars from any court the world has known.

The convention for establishing the Court of Arbitral Justice contains no provision concerning the law to be applied by the court. The convention for the establishment of the International Prize Court provides in Article VII that if the question in issue has been regulated by a treaty between the countries in litigation, the provision of this treaty should be binding upon the court. It also provides that "in the absence of such (treaty) provisions, the court shall apply the rules of international law. If no generally recognized rule exists, the court shall give judgment in accordance with the general principles of justice and equity". Russia and Japan had each objected at the time the convention was under discussion that inasmuch as the law relating to prize was not settled in all its details, an agreement upon the law to be applied should precede the establishment and operation of the court. After the Hague Conference adjourned and the 
question as to the ratification of the convention came before the government of Great Britain, that government made it known that it could not ratify unless an agreement was first reached as to certain branches of prize law. It proposed, therefore, an international conference of naval powers which should meet at London and reach an agreement concerning the law of prize. The conference assembled in December, 1908, and adjourned the last of February, I909, having agreed upon what is known as the Declaration of London, and which established a code of rules regulating the rights of neutrals and belligerents with respect to neutral commerce.

Should the act which provides for the Court of Arbitral Justice have made provision for the settlement in some similar fashion of the international law which shall be applied to the controversies the court is to determine? We do not regard such a provision as essential to the establishment of the court. The Courts of England and of the United States administer justice according to the principles of the common law without the codification of that law; and an international court can administer justice according to international law and international equity without waiting for the establishment of an international code, however desirable such a code may be. The development of international law has proceeded with a very slow step. It is still in a very imperfect and unsettled state. Mr. Choate told the New York Bar Association in 1908 that he did not know but that it would be a hundred years longer before a body of international law was developed to which all the nations would give their assent. To await the codification of the law and the acceptance of it by fortysix nations would be to postpone indefinitely the establishment of the Court.

The Hague Conference of I9O7 adopted the following resolution: "The Conference recommends to the Signatory Powers, the adoption of the project hereunto annexed of a convention for the establishment of a Court of Arbitral Justice and its putting in effect as soon as an accord shall be reached upon the choice of the judges and the constitution-of the Court."

The report of the delegates of the United States to the Conference made to the Secretary of State, Mr. Root, in calling attention to this resolution says:

"An analysis of the paragraph shows that the establishment of the court is not the expression of a mere wish or desire on the 
part of the Conference, but that it is a recommendation to the l'owers to unclertake the establishment of the court. In the next place, the project of convention, annexed to the recommenclation, is not to be submitted as a plan or as a model, int for adoption as the organic act of the court. Again, the convention annexed and made a part of the recommendation goes forth not only with the approval of the Conference but as a solemn act adopted by it, and finally accepting the convention as the organic act, the Conference recommends that the court be definitely and permanently established by the Powers as soon as they shall have agreed upon a method of appointing the judges, who, when appointed, thus constitute the court. It will be noted that the number of Powers necessary to establish the court is not stated, nor is the number of judges determined. It follows, therefore, that the Powers wishing to establish the court are free to adopt the project of convention, agree upon the method of choosing the judges, and establish the court at The Hague for the trial of cases submitted by the contracting Powers."

From this official explanation of the delegates it is made evident that The Hague Conference understood that the project of convention which it submitted was "the organic act of the court" and not the mere suggestion of a model or of a plan subject to modification and amendment and out of which might subsequently be developed the organic act of the court.

It is necessary, therefore, to consider the provisions contained in the organic act as proposed by the Conference. That act relates to the organization of the Court, its jurisdiction and its procedure.

Those provisions, contained in thirty-five articles, show that what is proposed is a permanent Court of Arbitral Justice, composed of judges who are to decide causes by judicial methods and under a sense of judicial responsibility. In this respect, it differs from the so-called court created by the First Conference. That court is not abrogated by the new court but is continued in existence. The court of 1899 is a court only in name. It provicles an arrangement for the selection of referees for each particular case, never consisting of the same persons. The court of 1907 is a real court composed of judges learned in the law.

Article I provides that the court shall be "composed of judges representing the various judicial systems of the world, and capable of ensuring continuity in jurisprudence of arbitration." And Article II provides, "The Judicial Arbitration Court is composed of judges and deputy judges chosen from persons of the highest 
moral reputation, and are fulfilling conditions qualifying them in their respective countries to occupy high legal posts, or be jurists of recognized competence in matters of international law." The judges are to be appointed for a term of twelve years. They are to be equal in rank, and are to enjoy diplomatic privileges and immunities in the exercise of their functions outside their own country. They are to receive an annual salary of 6,000 Netherland florins, approximately $\$ 2,400$. In the exercise of their duties during the session of the Court, they receive in addition the sum of Ioo florins per diem, approximately $\$ 40$ a day. They are further entitled to receive a traveling allowance fixed in accordance with regulations existing in their own country. They cannot accept from their own government or from that of any other power any remuneration for services connected with their duties in their capacity of thembers of the court. The general expenses of the court, including the salaries of the judges, are to be paid through the International Bureatu, and are to be borne by the contracting powers. A judge is forbidden to exercise his judicial functions in any case in which he has in any way taken part. Article VII provides that, "A judge may not exercise his judicial functions in any case in which he has, in any way whatever, taken part in the decision of a national tribunal, of a tribunal of arbitration, or of a commission of inquiry, or has figured in the suit as counsel or advocate for one of the parties. A judge cannot act as agent or advocate before the Judicial Arbitration Court or the Permanent Court of Arbitration, before a special tribunal of arbitration, or a commission of inquiry, nor act for one of the parties in any capacity whatsoever so long as his appointment lasts.". The seat of the court is established at The Hague "and cannot be transferred," so reads Article XI, unless absolutely obliged by circumstances, elsewhere. The delegation may choose, with the assent of the parties concerned, another site for its meetings, if special circumstances render such a step necessary. The court is to meet in session once a year. The session is to open the third Wednesday in June and to last until all the business on the agenda has been transacted. Provision is made by which the court may be summoned in extraordinary session and by which it need not meet in annual session if such meeting is unnecessary, there being no business to come before it. 
The organic act as drawn by the Conference provides concerning procedure in Article XXII that "The Judicial Court of Arbitration follows the rules of procedure laid down in the convention for the pacific settlement of international disputes, except in so far as the procedure is laid down in the present convention", and in Article XXXII that "the court itself draws up its own rules of procedure, which must be communicated to the contracting powers." In Article XXXII it is provided that "The court determines what language it will itself use, and what languages may be used before it." In Article XXV it is declared that "For all notices to be served, in particular on the parties, witnesses, or experts, the court may apply direct to the government of the State on whose territory the service is to be carried out. The same rule applies in the case of steps being taken to procure evidence. The requests addressed for this purpose can only be rejected when the power applied to considers them likely to impair its sovereign rights or its safety. If the request is complied with the fees charged must only comprise the expenses actually incurred. The court is equally entitled to act through the power on whose territory it sits." . The articles also provicle that decisions are to be arrived at by a majority of the judges present and that the judgment of the court must give the reasons on which it is based. It must contain the names of the judges taking part in it and be signed by the president and registrar. Each party pays its own costs and an equal share of the costs of the trial. The organic act has been most carefully drafted and contains the essential provisions which should be embodied in such a law.

It is true the act as proposed provides no way by which the court is to enforce its judgments. Blackstone, discoursing upon municipal law, tells us that of all the parts of a law the most effectual is the vindicatory, and that the main strength and force of a law consists in the penalty annexed to it. To say do this or avoid that, he says, is but lost labor unless it is also declared that the consequences of non-compliance shall be thus and so. In the sanction or penalty of the law lies its principal obligation.

The discussion of a possible international court has necessarily involved the question whether such a court can be of use unless authority is conferred upon it which will enable it to enforcee its judgment by an international police or an international military force. It has been argued that the nations ought to agree in es- 
tablishing the court, that if any state or nation which submits a controversy to the court's judgment should fail to comply with the court's decision, all the other nations shall put at the court's command so much of their military force as may be necessary to secure obedience to the decree. In not providing for such contingencies in the act which The Hague Conference submits we are not to conclude that the law is deficient in an essential or most essential requirement. The sanction which secures obedience to municipal laws does not consist exclusively or chiefly of the pains and penalties imposed by the law for its violation. The fact is that obedience to law is one of the highest of moral obiigations. Socrates so recognized it and it is related of him that he made a promise with himself to observe the laws of his counitry. A commentator remarks that "this is nothing more than what every good man ought both to promise and perform". He adds, and this the Governor of South Carolina needs to have impressed on his mind, "he ought to promise still further that he will exert all his power to compel others to obey them." Obedience to the law is also due to the compulsion of public opinion. Men obey the laws because they fear the disgrace which follows the repudiation of the standard of conduct prescribed by the community for its members. The force of a law is in the public opinion which enacted it and keeps it on the statute-book. Laws cannot be enforced except in so far as they accord with the public opinion of the community to which they apply. The dread of the community's condemnation is as certainly a deterrent influence as is the fear of the penalty which the law imposes upon those who break it. In most instances the effectiveness of the law is due to the respect which men entertain for public opinion, and the desire men have to be thought well of by the community in which they live. An international court is not therefore valueless because it is not provided with a sheriff and a policeman as the guarantors that its judgment will be enforced. If the court is to be dispensed with on that ground, we should go a step further and repudiate the whole body of rules which together constitute international law and dismiss them as altogether worthless because they are without a sanction.

In the very able address on the "Sanction of International Law" which $\mathrm{Mr} \mid$ Root delivered in 1908 before the American Society of -International Law, he made it very evident that after all the absence of a "sanction" in international law was not nearly so im- 
portant as many were inclined to suppose. The isolation of nations has broken down and they have ceased to be indifferent to the opinions which each entertains of gne another in the com= munity of nations. The nations most advanced in civilization, and they are the most powerful of states, well understand "that the laws established by civilization for the guidance of national conduct cannot be ignored with impunity." In alluding to the absence of technical "sanction" from international law, Mr. Root saịd :

"Nevertheless, all the foreign offices of the civilized world are eontinually discussing with each other questions of international law, both public and private, cheerfully and hopefully marshaling facts, furnishing evidence, presenting arguments, and bưilding up records, designed to show that the rules of international law require such and such things to be done or such and such things to be left undppe. And in countless cases nations are yielding to such arguments and shaping their conduct against their own apparent interests in the parficular cases under discussion, in obedience to the rules which are shown to be applicable. Why is it that nations are thus continually yielding to arguments with no apparent compulsion pehind them, and before the force of such arguments abąndoning purposes, modifying conduct, and giving redress for injuries? A careful consideration of this question seems to lead to the conclusion that the difference between municipal and international law, in respect of the existence of forces compelling obedience, is more apparent than real, and that there afe sanctions for the enforcement of international law no less real and established than those which secure obedience to municipal law."

It is not believed to be necessary that any provision should be made whereby the Arbitral Court should summon to its aid in the enforcement of its jugdgments, any constabulary or military power whatsoever. No provision of this kind is to be found in the articles establishing either the Permanent Court, the International Prize Court, or the Court of Arbitral Justice. Any nation which submits its controversies in good faith to any one of these courts, agrees thereby to carry into effect with the least possible delay the judgments which may be rendered.

The United States has submitted to international arbitration a number of questions which had previously been decided by the Supreme Court and in at least six of them, the tribunal of arbitration decided them adversely to the opinions rendered in the Supreme Court of the United States. (The cases on the Hia- 
watha, 67 U. S., 638; the Circassian, 69 U. S., I35; the Springbock, 72 U. S., I ; the Sir William Peel, $7^{2}$ U. S., $5^{17}$; the Volant, 72 U. S., I79; the Science, 72 U. S., I78.) In no one of these cases did the government hesitate to comply with the award. For one hundred years, the United States has been submitting its disputes to arbitration. We have had many such arbitrations and one who carefully examines the decisions rendered by the Arbitral Tribunals will come to the conclusion that they are inferior to those rendered in the Supreme Court of the United States. But not in a single instance has the government failed to abide by the award. This is nothing to its credit. It has kept faith with the arbitrators and could have taken no other course save with dishonor. Other nations have pursued a like course and there is no reason for supposing that any different course will be pursued by any nation which submits a controversy to the Arbitral Court.

The judgments of the Supreme Court of the United States in which States are concerned, are satisfied without the employment of force. It is believed that in the history of the Court but one instance exists in which force was used, and that was in 1808 . The case was that of the sloop Active which had been condemned in 1777 by the Pennsylvania Admiralty Court as prize to an armed vessel of that State, deciding against an adverse claim by one Olmstead. Congress reversed the judgment and granted an injunction forbidding the State Marshal to account to the State court for the proceeds. The injunction was disregarded and the money was paid in 1778 to the State court and delivered by it to the State Treasurer, Rittenhouse. The claimants in 1803 obtained a personal judgment for this money against the personal representative of Rittenhouse and were about to enforce it. The legislature of Pennsylvania thereupon passed an act denying the jurisdiction of the Federal Court and the validity of its judgment and directing the Governor to protect the representatives of Rittenhouse against any process of any Federal Court issued against them. Whereupon the Attorney-General applied in 1808 to the Supreme Court of the United States for a writ of mandamus commanding the judge of the District Court to enforce the judgments. The mandamus was awarded and the district judge issued his writ. When the attempt was made to serve it, the United States Marshal found he was obstructed by the bayonets of an armed guard which under the Governor's orders had been placed around the houses of the representatives of Rittenhouse, 
and in charge of General Bright commanding a brigade of militia. The Marshal summoned a posse comitatus of two thousand men, but delayed further action that there might be time for reflection. The Governor appealed to President Madison to interfere, who firmly refused. The State authorities gave way, the writ was served, and the money paid over. General Bright and his men were indicted, tried, convicted, and sentenced in the United States Circuit Court. The difficulty arose in the early history of the Court and was occasioned by a conviction that the Federal Courts were without jurisdiction because of the Eleventh Amendment.

The experience of the Supreme Court in enforcing its decrees without a resort to force affords encouragement to believe that the judgments of the Court of Arbitral Justice will be in like manner respected by any nation which submits a controversy for its adjudication. It is true that the Supreme Court has behind it the strength of the nation, and that no State is at all likely to measure its strength against that of the United States. On the other hand, no nation is to be compelled to submit its differences to the Arbitral Court and if it comes into the court with any particular question, it does so of its free will and accord. It can not be supposed that having voluntarily taken that step it will decline to abide by the judgment pronounced. It could not do so without covering itself with dishonor before the nations of the world.

Difficulty there had been some years earlier over a decision rendered by the court, in Chisholm v. Georgia, 2 Dallas, 419. In 1792 the Supreme Court issued a writ against the State of Georgia at the suit of Chisholm, a citizen of South Carolina, who sought payment of a private claim. The writ was returned duly served upon the Governor and Attorney-General. The State made no appearance and judgment was rendered by default. In the meanwhile the legislature of Georgia passed resolutions denying the obligation of the State either to answer the process or to obey the judgment of the court. Later, after judgment was actually rendered, the legislature announced the penalty of death against anyone who presumed to enforce the process within the State of Georgia. In this case there was no resistance to the Marshal. The collision was only threatened. It never came. The plaintiff delayed proceedings, awaiting action on the Eleventh Amendment which had already been proposed and soon was ratified by the States. Thereupon the Supreme Court renounced jurisdic- 
tion "in any case past or future" in which a State was served by a citizen of another State, and the matter ended.

The organic act proposed by the Conference is defective in that it does not determine the number of the judges or the manner in which they are to be appointed. Upon these matters, the Conference could come to no agreement, and it was left open, the understanding being that some conclusion might be reached through subsequent negotiations.

The Brazilian plan, that each nation invited to The Hague should have the right to name one of the judges, would result, in case it were adopted, in making the Court unwieldy. As Mr. Scott pointed out in his address at The Hague, forty-six judges form a judicial assembly, not a court. The Supreme Court of the United States only consists of nine members. The English Supreme Court of Judicature consists of thirty-three judges, but it is divicled into a High Court of Justice and a Court of Appeal. In the Court of Appeal there are nine judges. The High Court of Justice is divided into three divisions. In the King's Bench division there are eighteen judges, in the Chancery division fifteen, and in the Probate division and Admiralty division, only two. The suggestion that a Court of fifteen judges is large enough is sound. The convention establishing the International Prize Court fixed the number of judges at fifteen, and provided that nine should constitute a quorum. Is there any good reason why the same provision should not be incorporated into the convention respecting the Arbitral Court?

Mr. Choate addressed the Conference on two different occasions concerning the selection of the judges. He submitted ten slifferent propositions and urged, with all the earnestness of which he was capable, the adoption of some one of them, even though it should be accepted simply as a provisional scheme. One proposals was for a court of seventeen judges and that eight of the larger nations having a more numerous population and larger commercial and industrial interests, and therefore confronted with more frequent controversies, should have a constant represcntation in the court, while the smaller nations were each to have representation for a longer or shorter period by a system of rotation. Another proposal was for the Conference to determine by vote a definite number of nations who should each be authorized to appoint a juclge for the full term of the court. Still another proposal was that the Conference should elect a prescribed number of judges, each nation having an equal voice and 
casting one vote. The last of his proposals was that each signatory power should propose a judge and an assistant and that the list thus made should be submitted to each signatory power, and that every power voting at the same time should choose from this. list; each nation voting for fifteen judges and fifteen assistants, and the fifteen judges and the fifteen asistants who received the greatest number of votes should be declared elected.

M. de Martens submitted a plan which was that éach country designate an elector taken from the list of members of the Permanent Court and that these forty-five electors should in their turn choose fifteen judges, who should constitute the court.

Mr. Choate was ready to adopt any one of the ten plans, but the Conference rould agree upon none of them.

Article XV respecting the Prize Court is as follows:

"The judges appointed by the following contracting powers: Germany, the United States of America, Austria-Hungary. France, Great Britain, Italy, Japan and Russia, are always summoned to sit. The judges and deputy jutlges appointed by the other contracting powers sit by vote, as shown in the table annexed to the present convention, and thcir duties may be performed successively by the same person. The same judge may be appointed by several of the said powers."

It is difficult to understand why such a provision could be adopted as respects the Court of Prize, but could not be accepted as respects the Arbitral Court.

It would seem, too, that it should be entirely practicable to agree upon some uniform principle concerning the method by which a government entitled to appoint a judge to membership in the court should make the appointment. While the differences in the methods of governments make it impossible to agree upon a uniform mode of appointment, they should not make it impossible to reach an agreement upon a uniform principle. It ought to be possible to agree that each government entitled to appoint a judge should make the appointment in the same manner it appoints the judges in its own courts of last resort. A juclge selected by the United States should be nominated by the President and confirmed by the Senate. In England the appointment would be by the Crown acting on the advice of the Prime Minister, who generally would be governed by the advice of the Lord Chancellor. In France the appointment would be made by the I'resident, acting on the advice of the Minister of Justice. In Germany it would be made through the Federal Council and the Emperor. 
The International Court should be a world court, the court of all the nations. The existence of such a Court ought to appeal especially to the small nations, because it would secure to them that protection against more powerful states which their own strength could not afford. Before such a court all states wou!d be equal. "It is only," as James Brown Scott well said, "whin we leave the realm of law and face brute force that inequality appears. It is only when the sword is thrown upon the scales of justice that the balance tips."

But if the small and the great states cannot agree upon the choice of the judges of a world court, the failure to reach an understanding upon this essential point should not long deter the United States, England, Germany and the other great powers from coming to an agreement and establishing the court and putting it into immediate operation with the understanding that the other states would be admitted from time to time as soon as they could agree to accept the scheme as finally adopted.

In an important particular, I find myself unable entirely to agrec with the organic act as submitted by the Conference. Under that act the court not only has jurisdiction to decide questions of law, but it is also given concurrent jurisdiction with the Permanent Court of I 890 over questions other than those of a judicial nature, and which may be submitted by way of arbitration. It is also provided that a delegation of three judges is competent to settle the compromis referred to in Article 52 of the convention for the pacific settlement of international clisputes, and that it may do so in certain cases when the request is made only by one of the parties concerned. I have found it impossible to rid myself of the conviction that it would be better if the court could be restricted exclusively to questions of a judicial nature, and that all other questions should be left to the Permanent Court of 1899 . I would prefer a court, like the Supreme Court of the United States, which shall decide purely legal questions on the basis of respect for law. All through its history our Supreme Coutrt has endeavored to confine the exercise of its powers strictly to matters of a judicial character. The wisdom of its course has been amply justified. It would seem that there would also be some considerable advantage if the International Prize Court and the Court of Arbitral Justice should be merged in a single tribunal. It is difficult to see adequate reason for keeping them distinct. To unite them would increase the dignity of the Court. 